\title{
Pelaksanaan Penilaian Ranah Afektif Menggunakan Google Form di Era New Normal
}

\author{
1 Marno; ${ }^{2}$ Tsania Utsma Tausih \\ 1 \& 2Universitas Islam Negeri Maulana Malik Ibrahim Malang, Indonesia \\ 1 marno@pai.uin-malang.ac.id; 2 tsaniau1@gmail.com
}

\begin{abstract}
This article aims to determine the planning, implementation, as well supporting and inhibiting factors in the affective assessment process using Google Form in the New Normal era in PAI SMKN 2 Magetan using a qualitative research approach with descriptive research type. 1) affective assessment planning consists of conducting KI / KD, determining the objective of the assessment, making a grid, selecting the type of instrument, and making scoring guidelines; 2) the implementation of affective assessments consisting of designing the instrument design, socializing the filling of the Google Form, asking students to complete the affective assessment, data processing and reporting the results; 3) the supporting factors for the implementation of affective assessment with Google Form consist of all parties who have tried their best, the government provides concessions to schools, students and teachers communicate actively, assessments are objective, comprehensive, economical, safety, and students' health is guaranteed. The inhibiting factors for affective assessment using Google Form consist of decreased student learning motivation, students experience internet network problems, teachers cannot monitor students directly.
\end{abstract}

Keywords. Affective Assessment; Google Form; New Normal.

\begin{abstract}
Abstrak. Artikel ini bertujuan mengetahui proses perencanaan, pelaksanaan, serta faktor pendukung dan penghambat dalam proses penilaian afektif menggunakan Google Form di era New Normal pada mata pelajaran PAI SMKN 2 Magetan menggunakan pendekatan penelitian kualitatif dengan jenis penelitian deskriptif. Hasil penelitian ini terdiri dari : 1) perencanaan penilaian terdiri dari melakukan telaah $\mathrm{KI} / \mathrm{KD}$, menentukan tujuan penilaian, membuat kisi-kisi, memilih jenis instrumen, dan membuat pedoman penskoran; 2) pelaksanaan penilaian afektif terdiri dari merancang desain instrumen, mensosialisasikan pengisian Google Form, meminta murid mengisi penilaian afektif, pengolahan data dan pelaporan hasil; 3) faktor pendukung pelaksanaan penilaian afektif dengan Google Form terdiri dari seluruh pihak telah berusaha yang terbaik, pemerintah memberikan kelonggaran pada sekolah, siswa dan guru melakukan komunikasi secara aktif, penilaian bersifat objektif, komprehensif, ekonomis, keselamatan, dan kesehatan siswa terjamin. Faktor penghambat penilaian afekftif dengan Google Form terdiri dari motivasi belajar siswa yang menurun, siswa mengalami kendala jaringan internet, guru tidak bisa memantau siswa secara langsung.
\end{abstract}

Kata kunci. Penilaian Afektif; Google Form; New Normal. 
Marno; Tsania Utsma Tausih: Pelaksanaan Penilaian Ranah Afektif ...

\section{A. PENDAHULUAN}

Pendidikan ialah usaha sadar yang dilaksanakan oleh seorang guru untuk mendorong peserta didik agar belajar sesuai dengan potensi dan kemampuannya. Pendidikan bertujuan mengembangkan kemampuan dan potensi anak agar memiliki kekuatan spiritual keagamaan, berkepribadian, pengendalian diri, berakhlak mulia, memiliki kecerdasan, serta keterampilan yang dibutuhkan sebagai anggota masyarakat dan warga Negara (Nurbudiyani, 2013).

Dalam hal tersebut, guru harus mampu terus meningkatkan kualitas pembelajaran agar tujuan pembelajaran dapat tercapai secara maksimal. Guru harus mampu mendesain pembelajaran yang mampu meningkatkan motivasi dan minat siswa untuk terlibat aktif di dalam kelas. Guru juga harus mendesain instrumen penilaian yang mampu mengukur sejauh mana kemampuan siswa telah tercapai.

Penilaian memiliki kedudukan penting dalam berlangsungnya proses pembelajaran yang baik dan efektif sesuai dengan amanat Kurikulum 2013. Penilaian merupakan kegiatan yang berlangsung secara sistematis dan berkesinambungan guna mendapatkan informasi mengenai proses ataupun hasil belajar murid, dalam rangka menentukan keputusan berdasarkan kriteria yang sebelumnya telah ditentukan (Arifin, 2012). Standar penilaian Kurikulum 2013 yang diatur dalam Permendikbud no 66 tahun 2013 menerangkan bahwa, teknik penilaian yang saat ini digunakan harus meliputi penilaian ranah sikap, pengetahuan, dan keterampilan. Ketiga ranah tersebut memiliki kedudukan yang sama pentingnya dalam proses penilaian yang dilakukan oleh guru.

Kurikulum 2013 tidak hanya menitikberatkan kemampuan kognitif sebagai salah satu kunci kesuksesan siswa. Penilaian yang hanya dilakukan pada aspek pengetahuan, tidak akan bisa menggambarkan peran penilaian yang bisa dijadikan suatu pendekatan agar murid terdorong untuk belajar. Lebih dari itu, Kurikulum 2013 mengamanatkan pentingnya pendidikan karakter melalui sikap spiritual dan sosial yang terangkum dalam penilaian afektif. Pendidikan karakter menumbuhkan kebiasaan mengenai hal-hal yang baik, sehingga siswa bisa paham (kognitif) mengenai hal yang benar dan salah, mampu mengahayati dan merasakan (afektif) nilai-nilai yang benar serta mampu mengimplementasikannya (psikomotorik) (Abdulloh, \& Putu, 2013). Siswa tidak akan mencapai kesuksesan pembelajaran secara maksimal jika mereka tidak memiliki kemampuan afektif yang baik. Hasil belajar ranah pengetahuan dan keterampilan akan tercapai secara optimal jika para murid memiliki kemampuan sikap (afektif) yang tinggi (Imtihan, dkk, 2017). Penilaian ranah sikap meliputi penilaian terhadap perilaku, minat, sikap, konsep diri, moral, nilai, dan norma yang dimiliki siswa seperti tanggung jawab mereka dalam mengikuti proses pembelajaran.

Salah satu mata pelajaran yang diandalkan untuk memberikan penekanan terhadap pendidikan karakter adalah PAI. Dalam hal ini, proses pembelajaran PAI harus memosisikan ajaran agama Islam sebagai objek kajian yang memandang Islam sebagai sistem moral dan sistem nilai yang tidak hanya diketahui, dan dipahami, tetapi juga harus diimplementasikan dalam perilaku sehari-hari di kehidupan bermasyarakat (Betwan, 2019). PAI di sekolah ialah salah satu mata pelajaran atau program studi yang memiliki tujuan untuk menghasilkan siswa-siswi dengan jiwa keagamaan dan ketaatan dalam mengerjakan perintah agamanya, serta memiliki dan menguasai pengetahuan agama yang mendalam (Anwar, 2014). Artinya, PAI merupakan bidang ilmu yang diajarkan kepada peserta didik dengan usaha secara sadar dan sistematis untuk membimbing, mengarahkan, menghayati, mengimani, serta mengimplementasikan nilai ajaran agama Islam dalam kehidupan sehari-hari.

Proses penilaian afektif dalam pembelajaran PAI bisa dilaksanakan melalui beberapa cara seperti: observasi guru, jurnal guru, penilaian diri, dan penilaian antar 
teman. Sayangnya, pandemi Covid-19 yang saat ini terjadi di seluruh dunia telah memberikan dampak yang besar terhadap berbagai macam variabel pembelajaran, termasuk proses penilaian. Pandemi Covid-19 saat ini menuntut seluruh jenjang pendidikan di Indonesia untuk melaksanakan pembelajaran secara dalam jaringan (daring) atau online. Akibatnya, proses penilaian afektif yang biasanya dilakukan oleh guru melalui pengamatan langsung saat pertemuan tatap muka, tentu tidak bisa dilaksanakan seperti sebelumnya. Seluruh elemen sekolah baik guru ataupun siswa dituntut untuk beradaptasi dengan pola kehidupan baru yang disebut dengan istilah New Normal. New Normal adalah melakukan aktivitas seperti kehidupan sebelumnya namun tetap memperhatikan protokol kesehatan (Muntaha, \& Anwar, 2020). New Normal juga merupakan upaya pemerintah untuk menjaga stabilitas kehidupan warga negara dengan tetap menjalankan berbagai macam sektor kehidupan menggunakan kebiasaan baru seperti menjaga jarak, menghindari kerumunan, menggunakan masker, dan mencuci tangan.

Di era New Normal ini, guru harus menciptakan instrumen penilaian afektif yang tetap efektif dan efisien agar proses penilaian tetap bisa dilaksanakan bagaimanapun keadaannya. Dengan begitu, tujuan pembelajaran juga tetap dapat tercapai secara maksimal. Oleh karenanya, peneliti sangat tertarik untuk mengetahui proses pelaksanaan penilaian ranah afektif di era New Normal ini. Salah satu sekolah yang telah berhasil melaksanakan penilaian afektif pada mata pelajaran PAI di era New Normal saat ini adalah SMKN 2 Magetan.

Guru PAI di SMKN 2 Magetan telah melaksanakan penilaian afektif menggunakan Google Form sebagai solusi dari pembelajaran daring saat ini. Google Form ialah layanan berbasis online dari Google yang berguna untuk membuat formulir online, menghimpun data, komentar, yang kemudian akan disusun menggunakan spreadsheet (Jahroh, 2018). Layanan Google Form ini biasanya digunakan oleh beberapa pihak untuk melaksanakan survey jejak pendapat, mengelola pendaftaran, membuat tes, ataupun kuis yang dilaksanakan secara online. Di dalam dunia pendidikan, Google Form memiliki beberapa fungsi diantaranya, untuk membuat ujian atau penilaian secara online, menghimpun pendapat orang lain secara online, menghimpun data guru dan siswa secara online, membuat formulir pendaftaran online, serta menyebarluaskan kuisioner secara online (Batubara, 2016). Ditambah lagi, Google Form juga memiliki beberapa keunggulan yang terdiri dari: mudah dioperasikan, ekonomis, bebas tidak terikat ruang dan waktu, responsif, serta mudah dibagikan. Beberapa alasan diataslah yang melatar belakangi pemilihan Google Form sebagai instrumen penilaian afektif oleh guru PAI SMKN 2 Magetan di era New Normal saat ini.

\section{B. METODE}

Penelitian ini menggunakan pendekatan penelitian kualitatif yang bertujuan memahami peristiwa yang telah dialami subjek penelitian dengan menggunakan data deskripsi dalam bentuk kata-kata serta bahasa, atas suatu konteks khusus yang terjadi secara alamiah dengan menggunakan berbagai jenis metode alamiah (Moleong, 2005). Adapun jenis penelitian yang digunakan adalah penelitian deskriptif. Penelitian kualitatif deskriptif berorientasi pada paham konstruktivisme atau interpretif yang memiliki tujuan agar mengungkap realitas secara ilmiah, dengan analisis data berupa kalimat rinci yang logis, dan sistematis (Arifin, 2013).

Penelitian ini dilaksanakan di SMKN 2 Magetan menggunakan sumber penelitian primer dan sekunder. Sumber primer terdiri dari Kepala Sekolah SMKN 2 Magetan, Wakil Kepala Sekolah Kurikulum SMKN 2 Magetan, guru PAI Kelas XI SMKN 2 Magetan, serta enam siswa kelas XI SMKN 2 Magetan. Sedangkan, sumber data sekunder dalam penelitian 
Marno; Tsania Utsma Tausih: Pelaksanaan Penilaian Ranah Afektif ...

ini berupa dokumen kurikulum SMKN Magetan, serta referensi lain yang akan melengkapi data penelitian ini.

Teknik pengumpulan data yang digunakan oleh peneliti meliputi: wawancara, observasi, serta dokumentasi. Wawancara yang dilaksanakan meliputi wawancara secara terstruktur dan tidak terstruktur dengan beberapa pihak yang terdiri Kepala Sekolah SMKN 2 Magetan, Wakil Kepala Sekolah Kurikulum SMKN 2 Magetan, guru PAI Kelas XI SMKN 2 Magetan, serta enam siswa kelas XI SMKN 2 Magetan. Dalam penelitian ini, proses observasi akan dilaksanakan secara langsung ataupun tidak langsung terhadap proses pelaksanaan penilaian ranah afektif menggunakan Google Form di era New Normal pada mata pelajaran PAI kelas XI SMKN 2 Magetan. Selanjutnya, proses pencarian data menggunakan teknik dokumentasi pada penelitian ini akan dilakukan untuk memenuhi data-data yang berkaitan dengan kurikulum ataupun pembelajaran yang tidak bisa diperoleh melalui wawancara dan observasi.

Analisis data yang digunakan pada penelitian ini terdiri dari beberapa tahapan yang terdiri dari : (1) pengumpulan data, pada tahap ini peneliti akan menjadi instrumen utama yang mencari berbagai jenis data yang diperlukan; (2) reduksi data, pada tahap ini peneliti melakukan perangkuman, pemilihan, serta penyederhanaan data agar data-data yang penting dan pokok dapat dikumpulkan menjadi satu; (3) penyajian data, ini merupakan proses penyusunan data yang telah direduksi untuk tujuan pengambilan tindakan ataupun kesimpulan penelitian. Data akan disajikan secara sistematis, utuh, dan terpadu; (4) kesimpulan, pada tahap ini penelitian akan membuat kesimpulan berdasarkan fokus penelitian, sehingga menemukan jawaban atas fokus permasalahan tersebut.

Kegiatan pengabsahan data untuk menghasilkan data penelitian yang valid dan akuntabel dalam penelitian ini meliputi: kegigihan dalam pengamatan (persistent observation), dan triangulasi. Triangulasi merupakan proses pengecekan keseluruhan data penelitian yang telah dikumpulkan melalui berbagai cara dalam kurun waktu terentu yang berasal dari berbagai sumber baik primer ataupun sekunder. Jenis triangulasi dalam penelitian ini terdiri dari: triangulasi sumber, triangulasi teknik pengumpulan data, dan triangulasi waktu.

\section{HASIL DAN PEMBAHASAN}

\section{Perencanaan Pelaksanaan Penilaian}

Tahap perencanaan merupakan tahapan bagi guru untuk melaksanakan aktivitasaktivitas sebelum proses pelaksanaan penilaian dilaksanakan. Tahap perencanaan memiliki peran sangat penting dalam proses penilaian. Tahap ini akan menjadi basis awal yang akan menjamin kelancaran proses-proses setelahnya. Perencanaan yang baik akan memastikan proses pelaksanaan juga dapat berlangsung dengan baik.

Tahap perencanaan penilaian afektif yang diatur dalam Juknis Penyusunan Perangkat Penilaian Afektif di SMA oleh Direktorat Pembinaan SMA terdiri dari beberapa tahapan diantaranya : penelaahan KI/KD, menentukan tujuan penilaian, menentukan kisikisi, menentukan instrumen penilaian, memilih jenis dan pedoman penskoran, merakit instrumen, melakukan uji coba, menganalisis hasil uji coba, serta menyempurnakan dan merevisi instrumen penilaian afektif tersebut.

Berdasarkan data temuan penelitian menyatakan bahwa beberapa tahapan perencanaan yang dilakukan oleh guru PAI SMKN 2 Magetan telah sesuai dengan tahapan perencanaan yang diatur dalam Juknis Penyusunan Perangkat Penilaian Afektif di SMA diatas. Meskipun begitu, terdapat beberapa tahapan dalam perencanaan tersebut yang tidak dilaksanakan oleh guru PAI SMKN 2 Magetan. Tahapan perencanaan pelaksanaan penilaian ranah afektif menggunakan Google Form di era New Normal pada mata pelajaran PAI SMKN 2 Magetan terdiri dari: 
a. Melakukan Telaah KI/KD

Tahapan ini tetap harus dilaksanakan meskipun pembelajaran tidak bisa dilaksanakan secara tatap muka di dalam kelas. Dari KI/KD inilah guru akan mengetahui bagaimana proses pelaksanaan serta tujuan penilaian ini akan dicapai.

Berdasarkan amanat Menteri Pendidikan dan Kebudayaan, sekolah tidak diperkenankan memberikan beban tugas yang berlebihan kepada para siswa. Sekolah harus memprioritaskan kesehatan dan keselamatan siswa. Akibatnya, dalam penilaian ranah afektif menggunakan Google Form di era New Normal ini guru PAI SMKN 2 Magetan hanya menggunakan KI/KD yang paling penting untuk diajarkan kepada siswa, utamanya disaat pembelajaran daring ini. Salah satu KI/KD tersebut adalah mengenai pentingnya berperilaku jujur dalam kehidupan sehari-hari.

b. Menentukan Tujuan Penilaian

Tujuan penilaian dibuat untuk mengetahui sejauh mana indikator pembelajaran telah tercapai. Sasaran dilaksanakannya proses penilaian afektif bukan kemampuan pengetahuan siswa, melainkan perilaku peserta didik tersebut (Sukanti, 2011). Tujuan dalam temuan penelitian ini menyatakan bahwa siswa mampu berani menunjukkan dan mengimplementasikan perilaku berani bersikap jujur selama pembelajaran daring. Tujuan ini telah sesuai dengan rumusan tujuan penilaian afektif oleh Suharsimi Arikunto yang menjelaskan bahwa penilaian afektif dilaksanakan guna memafhumi tingkat perubahan perilaku yang berhasil dicapai murid serta memafhumi sikap yang ditunjukkan siswa terhadap suatu mata pelajaran. Sikap ini bisa berbentuk baik (positif) atau buruk (negatif) (Arikunto, 2003)

c. Membuat Kisi-kisi

Kisi-kisi akan membantu guru dalam mengetahui hal-hal yang harus tercantum dalam penilaian tersebut. Kisi-kisi dibuat berdasarkan materi yang telah disampaikan kepada siswa. Dalam hal ini, guru PAI SMKN 2 Magetan membuat 20 kisi-kisi penilaian afektif yang terdiri dari pernyataan negatif dan positif. Jumlah penyataan atau pertanyaan dalam penilaian afektif seharusnya tidak membuat peserta didik jenuh, alangkah baiknya bisa dikerjakan dengan waktu kurang dari 30 menit (Direktorat Pembinaan SMA, 2010). Kisi-kisi tersebut telah memuat objek penilaian sikap yang terdiri dari: sikap peserta didik terhadap mata pelajaran, sikap terhadap guru pengampu mata pelajaran, sikap terhadap berlangsungnya proses pembelajaran, sikap terhadap materi-materi yang dipelajari, sikap yang berkaitan dengan nilai tertentu yang ingin ditanamkan kepada para siswa (Setiadi, 2016).

d. Menentukan Media dan Teknik Penilaian

Media ialah perantara yang akan menyampaikan pesan guru kepada murid. Media akan membuat proses penilaian berlangsung lebih efektif dan efisien. Penilaian afektif di era New Normal pada mata pelajaran PAI SMKN 2 Magetan menggunakan Google Form sebagai medianya. Google Form merupakan suatu sistem yang berisi template formulir untuk tujuan memperoleh informasi penggunanya (Untung, Ninda, \& Moch. Sandi, 2018)

Teknik penilaian yang digunakan ialah teknik penilaian diri. Penilaian diri (selfassessment), adalah jenis teknik penilaian yang meminta para siswa untuk menunjukkan keunggulan dan kekurangan yang mereka miliki yang berhubungan dengan pencapaian kompetensi (Saftari \& Fajriah, 2019). Teknik penilaian self-assessment secara bertahap akan membantu peserta didik dalam mengekspresikan diri mereka secara objektif. Teknik ini juga akan menumbuhkan rasa percaya diri, kebiasaan jujur, dan bertanggung jawab dalam memberikan penilaian pada dirinya sendiri.

e. Memilih Panduan Penskoran

Pada penilaian afektif terdapat beberapa pilihan instrumen penilaian seperti Rating Scale, daftar cek, ataupun Skala Likert. Pada penelitian ini, guru PAI SMKN 2 Magetan 
menggunakan Skala Likert. Skala Likert ialah skala yang mengukur argument, sikap, serta persepsi seseorang mengenai suatu fenomena dalam dunia pendidikan (Saftari \& Fajriah, 2019). Skala Likert merupakan jenis skala penilaian afektif yang paling umum karena mampu mengungkap dan menunjukkan sejauh mana sikap yang dimiliki oleh responden (Kusumawati, 2015). Terdapat empat kriteria penilaian yang digunakan dalam Skala Likert yaitu: selalu, sering kadang-kadang, dan tidak pernah. Untuk pernyataan positif skor akan dimulai dari 4 menuju 1 untuk indikator selalu sampai tidak pernah. Sedangkan, pada pernyataan negatif skor akan dimulai dari 1 menuju 4 untuk indikator selalu sampai tidak pernah.

\section{Pelaksanaan Penilaian}

Tahap ini merupakan tahapan paling penting dari semua tahapan pelaksanaan penilaian afektif menggunakan Google Form di era New Normal pada mata pelajaran PAI kelas XI SMKN 2 Magetan. Penilaian ranah afektif berfokus pada pada sikap serta minat yang ditunjukkan oleh peserta didik seperti kepercayaan diri, tanggung jawab, disiplin, dan kejujuran. Selain itu, disebutkan pula dalam pasal 3 UU no 20 tahun 2003 bahwa, sekolah dan guru memiliki peran yang penting dalam mempersiapkan peserta didik menjadi manusia yang beriman, berkarakter, berakhlak mulia, dan bertanggung jawab. Penilaian ranah afektif haruslah berfokus pada sikap yang akan dipercaya dan diimplementasikan oleh siswa.

Tahapan yang dilalui oleh guru PAI SMKN 2 Magetan dalam proses pelaksanaan penilaian afektif menggunakan Google Form di era New Normal terdiri dari:

a. Merancang Desain Instrumen Penilaian Google Form.

Desain instrumen dibuat setelah memilih Google Form dengan teknik penilaian diri sebagai instrumen penilaian afektif di era New Normal saat ini. Google Form memiliki tampilan yang menarik. Aplikasi ini mempunyai berbagai jenis template yang membuat tampilan kuesioner dan kuis online tersebut semakin berwarna, dan menarik (Jahroh, 2018).

b. Mensosialisasikan Pengisian Penilaian Ranah Afektif Menggunakan Google Form di era New Normal

Dalam proses pensosialisasian guru PAI SMKN 2 Magetan menekankan pentingnya pendidikan karakter sesuai amanat UU no 20 tahun 2003. Pendidikan karakter tidak hanya dipahami dan dihayati oleh siswa, melainkan juga harus diimplementasikan dalam kehidupan sehari-hari. Pendidikan karakter akan menumbuhkan kebiasaan mengenai halhal baik seingga siswa dapat menguasai seluruh ranah penilaian baik kognitif, afektif, ataupun psikomotorik.

c. Siswa Mengisi Penilaian Afektif Menggunakan Google Form

Dalam proses pengisian penilaian afektif menggunakan Google Form ini dapat diketahui bahwa nilai-nilai yang bermakna bagi siswa agar mereka berkontribusi positif bagi dirinya sendiri, dan orang lain. Setiap pernyataan yang termuat dalam Google Form berfokus pada sikap siswa kepada dirinya sendiri, orang tua, guru, saudara, ataupun teman. Penilaian afektif menggunakan Google Form di era New Normal ini telah memenuhi jenjang ranah afektif oleh Bloom dan David Krathwol yang terdiri dari: (1) penerimaan (receiving), peserta didik memiliki kepekaan atas rangsangan yang diberikan oleh guru. Indikator dari penerimaan adalah peserta didik mampu: bertanya, menggunakan, membuat pilihan, membuat deskripsi, menyeleksi, memberikan, menyebutkan, menunjukkan, mengulangi (Sukanti, 2011); (2) partisipasi (participation), peserta didik akan bereaksi dengan memberikan perhatian dan berpartisipasi aktif dalam suatu acara yang diagendakan secara sukarela. Indikator dari partisipasi adalah peserta didik mampu: menjawab pertanyaan atau soal, membantu teman atau orang lain, membuat pilihan, berdiskusi, saling menghormati, saling memberi, memiliki kemampuan membaca, menulis., menghafal, 
melaporkan, menceritakan (Sukanti, 2011); (3) penilaian dan penentuan sikap (valuing), pada tahap ini peserta didik akan memiliki kemampuan untuk menilai sesuatu serta menyesuaikan diri atas penilaian tersebut. Terdapat beberapa indikator dalam tahap ini diantaranya, siswa mulai menggambarkan, melengkapi, membedakan, mengikuti, menerangkan, membentuk, mengusulkan, menggabung, mengundang, melaporkan, mengambil bagian, dan mempelajari; (4) organisasi (organization), merupakan kemampuan anak untuk memuat suatu sistem nilai yang akan digunakan sebagai panduan, pegangan, dan pedoman dalam kehidupan (Winkel, 2004). Indikator yang digunakan dalam tahap ini adalah menerangkan, memodifikasi, mengorganisir, membandingkan, melengkapi, mengintegrasi, dan mensintesis; (5) pembentukan pola hidup (characterization by a value), peserta didik mulai memiliki kemampuan untuk menghayati nilai-nilai kehidupan sehingga, mereka kemudian menjadikan nilai-nilai tersebut sebagai pegangan dalam menentukan langkah dan pilihan kehidupan mereka sendiri. Indikator pada tahap ini adalah ketika peserta didik mampu membedakan beberapa hal, menerapkan suatu nilai, mengusulkan pendapat atau usulan, mempengaruhi orang lain, memperagakan sesuatu yang mereka ketahui, memodifikasikan, memberika pertunjukkan, memecahkan masalah (Sukanti, 2011).

d. Pengolahan data dan pelaporan hasil

Tahapan ini merupakan tahap terakhir yang akan menjadi penyempurna tahaptahap sebelumnya. Tahapan ini juga menjadi tolak ukur efektivitas suatu proses pelaskanaan penilaian. Penilaian yang efektif adalah penilaian yang melalui beberapa tahapan seperti: perencanaan, pelaksanaan, pengolahan nilai, dan pelaporan hasil penilaian.

Penggunaan media Google Form sangat membantu guru dalam hal pengolahan data siswa. Sebagaimana kita tahu, Google Form memiliki salah satu kelebihan yaitu seluruh data yang masuk didalamnya akan tersusun secara otomatis dalam bentuk spreedsheets. Selain itu, Google Form juga menyediakan diagram, dan persentase atas setiap indikator yang digunakan dalam formulir tersebut.

Pada tahap pelaporan hasil, guru akan melaporkan hasil jawaban peserta didik kepada wali murid dalam bentuk data deskriptif. Hasil penilaian afektif selalu berupa data deskriptif yang menjelaskan kemampuan sikap siswa selama pembelajaran.

\section{Faktor Pendukung/Penghambat}

Proses penilaian akan berlangsung secara efektif jika tujuannya dapat dicapai. Selain itu, penilaian yang efektif merupakan penilaian yang berhasil dilaksanakan sesuai dengan perencanaan yang sebelumnya telah dibuat. Namun, tidak bisa dipungkiri bahwa dalam setiap proses penilaian selalu terdapat faktor pendukung dan faktor penghambat yang nantinya akan menjadi acuan bagi guru untuk terus memperbaiki kualitas penilaian kedepannya.

Faktor pendukung pelaksanaan penilaian ranah afektif menggunakan Google Form di era New Normal pada mata pelajaran PAI SMKN 2 Magetan terdiri dari :

a. Seluruh pihak baik kepala sekolah, guru, dan siswa telah bekerjasama semaksimal mungkin demi mewujudkan penilaian ranah afektif yang efektif dan efisien di era New Normal. Kerjasama tim merupakan kunci kesuksesan suatu program. Dalam hal ini, kepala sekolah mampu melaksanakan perannya dalam pengawasan dan pemberian instruksi kepada guru sehingga guru dapat mewujudkan penilaian afektif yang maksimal. Guru PAI SMKN 2 Magetan juga terbukti sangat adaptif dan tanggap melalui berbagai kondisi dan situasi. Sebagaimana diketahui, guru memang harus mampu bersikap fleksibel, adaptif, terhadap segala bentuk perubahan yang terjadi dalam pembelajaran. Guru harus tetap menyuguhkan kualitas kegiatan pembelajaran dan penilaian yang terbaik. 
Marno; Tsania Utsma Tausih: Pelaksanaan Penilaian Ranah Afektif ...

b. Pemerintah memberikan kelonggaran kepada pihak sekolah.

c. Guru dan siswa tetap melaksanakan komunikasi secara aktif. Komunikasi memiliki peran yang amat penting dalam proses pembelajaran. Komunikasi yang baik antara guru dan siswa akan mempermudah tercapainya kompetensi dan tujuan pembelajaran. Siswa dan guru yang terlibat aktif dalam proses evaluasi kemajuan belajar menjadi salah satu indikator efektivitas suatu penilaian (Rohmat, 2015)

d. Penilaian bersifat objektif, komprehensif, praktis, dan ekonomis. Penilaian yang objektif adalah penilaian yang dibuat berdasarkan keadaan yang sebenarnya (Anis, 1996). Penilaian yang komprehensif ialah penilaian yang bersifat menyeluruh. Penilaian ini juga mampu menunjukkan sejauh mana penguasaan siswa terhadap suatu kompetensi dan membantu siswa dalam memahami dirinya (Kunandar, 2014). Penilaian juga harus bersifat praktis dan ekonomis, artinya penilaian mudah dilaksanakan, bahasa yang digunakan sesuai dengan kaidah, mudah dimengerti, tidak menimbulkan bias, memiliki pedoman yang jelas, tidak memerlukan banyak biaya, dan tidak menyita banyak waktu.

e. Keselamatan, dan kesehatan siswa terjamin. Saat ini, Wabah Covid-19 telah menjadi bencana kesehatan yang menyerang masyarakat di seluruh dunia. Seluruh negara di dunia sedang menyusun kebijakan dan langkah-langkah terbaik yang mampu meminimalisir penyebaran virus ini, termasuk Indonesia. Hal ini juga berdampak besar bagi bidang pendidikan yang mana di era New Normal saat ini prioritas utama yang harus diperhatikan oleh lembaga sekolah bukan lagi ketercapaian seluruh kompetensi pembelajaran, melainkan keselamatan dan kesehatan siswa.

Faktor penghambat pelaksanaan penilaian ranah afektif menggunakan Google Form di era New Normal pada mata pelajaran PAI SMKN 2 Magetan terdiri dari:

a. Motivasi belajar siswa yang menurun. Motivasi dan belajar merupakan dua hal yang memiliki hubungan timbal balik satu dengan yang lain. Dua hal ini saling memengaruhi dalam berjalannya proses pembelajaran. Motivasi memegang kendali untuk mengontrol semangat seseorang dalam belajar. Motivasi adalah energi yang ada dalam diri seseorang yang mampu memberikan stimulus positif sehingga orang tersebut lebih bersemangat dalam melakukan sesuatu dalam hidupnya. Semakin tinggi motivasi peserta didik dalam mengikuti pembelajaran maka semakin tinggi pula kemungkinan tercapainya kompetensi dan tujuan pembelajaran. Dalam hal ini, penyebab menurunnya motivasi belajar siswa di era New Normal adalah karena mereka terganggu dengan kegiatan-kegiatan lain di saat pembelajaran, siswa tidak bisa mengatur waktu belajar selama pembelajaran daring, suasana belajar dirumah tidak semenarik pembelajaran di kelas.

b. Siswa mengalami kendala jaringan internet. Ini merupakan salah satu kendala paling banyak dikeluhkan selama proses pembelajaran daring berlangsung di era New Normal saat ini. Letak geografis rumah siswa dengan akses internet yang tidak baik memberikan dampak yang besar dalam proses pelaksanaan pembelajaran daring. Akibatnya, pelaksanaan pembelajaran dan penilaian tidak bisa berlangsung lebih efektif jika dibandingkan dengan pembelajaran dan penilaian luring.

c. Guru tidak bisa memantau siswa secara langsung

Pembelajaran daring di era New Normal saat ini menyebabkan guru tidak bisa memantau perkembangan siswa secara langsung. Ini merupakan hal baru dalam sistem pembelajaran di Indonesia. Dalam pembelajaran luring, guru mampu mengamati perkembangan dan ketercapaian kompetensi yang telah dikuasai siswa. Guru dan siswa sama-sama memerlukan waktu untuk bisa beradaptasi lebih baik dalam pembelajaran daring saat ini. 


\section{KESIMPULAN}

Perencanaan pelaksanaan penilaian ranah afektif menggunakan Google Form di era New Normal pada mata pelajaran PAI kelas XI SMKN 2 Magetan terdiri dari beberapa tahapan, yaitu : (a) melakukan telaah KI/KD; (b) menentukan tujuan penilaian; (c) membuat kisi-kisi penilaian; (d) menentukan media dan jenis teknik penilaian; (e) menentukan penskoran penilaian afektif. Hal ini sesuai dengan Juknis Penyusunan Perangkat Peniaian Afektif SMA/SMK yang diterbitkan oleh Direktorat Pembinaan SMA.

Pelaksanaan penilaian ranah afektif menggunakan Google Form di era New Normal pada mata pelajaran PAI kelas XI SMKN 2 Magetan terdiri dari beberapa tahapan, yaitu : (a) merancang desain instrumen penilaian yang akan digunakan; (b) mensosialisasikan instrumen ranah afektif menggunakan Google Form tersebut kepada kelas XI SMKN 2 Magetan; (c) meminta peserta didik kelas XI SMKN 2 Magetan untuk mengisi penilaian afektif menggunakan Google Form; (d) pengolahan data dan pelaporan hasil penilaian peserta didik kelas XI SMKN 2 Magetan. Proses pelaksanaan penilaian ranah afektif menggunakan Google Form di era New Normal pada mata pelajaran PAI kelas XI SMKN 2 Magetan telah melaksanakan amanat pendidikan karakter sesuai dengan UU no 20 tahun 2003. Pelaksanaan penilaian afektif menggunakan Google Form ini juga telah memenuhi jenjang ranah afektif oleh Bloom dan David K. yang terdiri dari: penerimaan, partisipasi, penilaian, organisasi, dan pembentukan pola.

Faktor pendukung dalam pelaksanaan penilaian ranah afektif menggunakan Google Form di era New Normal pada mata pelajaran PAI kelas XI SMKN 2 Magetan meliputi : (a) seluruh pihak baik itu kepala sekolah, guru, dan siswa telah berusaha semaksimal mungkin dalam mewujudkan proses penilaian afektif yang efektif dan efisien di era New Normal ini; (b) pemerintah memberikan kelonggaran kepada pihak sekolah; (3) siswa dan guru tetap bisa melakukan komunikasi secara aktif melalui media online; (d) siswa tidak merasa terbebani dengan penilaian afektif menggunakan Google Form ini; (e) penilaian afektif menggunakan Google Form mudah dioperasikan, ekonomis, objektif, praktis dan komprehensif. Faktor penghambat dalam pelaksanaan penilaian ranah afektif menggunakan Google Form di era New Normal pada mata pelajaran PAI kelas XI SMKN 2 Magetan meliputi: (a) motivasi belajar siswa yang semakin menurun karena mulai jenuh dengan pelaksanaan pembelajaran online di era New Normal saat ini; (b) guru tidak bisa memantau perkembangan peserta didik secara langsung; (c) kendala jaringan internet di rumah guru dan siswa.

Pada dasarnya penilaian afektif tetap bisa dilaksanakan secara maksimal di era New Normal saat ini. Guru bisa mendesain instrumen penilaian afektif yang paling efektif dan efisien sesuai dengan keadaan dan kondisi peserta didik. Salah satu media yang efektif dan efisien untuk digunakan guru dalam penilaian afektif di era New Normal ini adalah Google Form. Google Form memiliki beberapa kelebihan yang sangat membantu guru dan siswa dalam pelaksanaan penilaian afektif saat ini. Proses penilaian yang berjalan dengan baik, menunjukkan kualitas kegiatan pembelajaran yang tetap tinggi, meskipun tidak ada pertemuan tatap muka secara langsung antara guru dan siswa. Siswa tetap mampu mencapai kompetensi-kompetensi pembelajaran secara maksimal. 


\section{DAFTAR PUSTAKA}

Amalia, A., \& Fatonah, S. (2020). Penerapan Pembelajaran Daring Dragonlearn pada Era Pandemic Covid-19(Studi Kasus di MI Ma'had Islam Kopeng). ISEJ : Indonesian Science Education Journal, 1(3), 148-164. Retrieved from https://siducat.org/index.php/isej/article/view/81

Anwar, S. 2014. Desain Pendidikan Agama Islam, Yogyakarta: Idea Press.

Arifin, Z. 2012. Evaluasi Pembelajaraan. Bandung: Remaja Rosdakarya Offset.

Arifin. 2013. Penelitian Pendidikan. Yogyakarta: Lilin Persada Press.

Arikunto, S. 2003. Dasar-Dasar Evaluasi Pendidikan. Jakarta: PT Remaja Rosdakarya. 178

Bachri. B. S. 2010. Meyakinkan Validitas Data melalui Triangulasi pada Penelitian Kualitatif. Jurnal Teknologi Pendidikan, 10 (1),

Batubara, H. H. 2016. Penggunaan Google Form sebagai Alat Penilai Kinerja Dosen di Prodi PGMI Uniska Muhammad Arsyad Al Banjari. Al-Bidayah: Jurnal Pendidikan Dasar Islam, 8 (1). https://doi.org/10.14421/al-bidayah.v8i1.91.

Betwan. 2019. Pentingnya Evaluasi Afektif pada Pembelajaran PAI di Sekolah. Al-Fikri: Jurnal Studi dan Penelitian Pendidikan Islam, 2 (1), 47. http://dx.doi.org/10.30659/jspi.v2i1.4015.

Direktorat Pembinaan SMA. 2010. Juknis Penilaian Afektif SMA. Jakarta: Direktorat Pembinaan SMA.

Firmansyah, Y., Kardina, F. 2020. Pengaruh New Normal di Tengah Pandemi Covid 19 Terhadap Pengelolaan Sekolah dan Peserta Didik. Jurnal Buana Ilmu, 4 (2), https://doi.org/10.36805/bi.v4i2.1107.

Hamid, A., Sudira, P. 2013. Penanaman Nilai-Nilai Karakter Siswa SMK Salafiyah Prodi TKJ Kajen Margoyoso Pati Jawa Tengah. Jurnal Pendidikan Vokasi, 3 (2). https://doi.org/10.21831/jpv.v3i2.1592.

Imtihan, N., Zuchdi, D., dan Istitono. E. (2017). Analisis Problematika Penilaian Afektif Peserta Didik Madrasah Aliyah. Schemata: Jurnal Pasca Sarjana IAIN Mataram, 6(1), 63-80. https://doi.org/10.20414/schemata.v6i1.836.

Ismanto. 2014. Evaluasi Hasil Belajar Pendidikan Agama Islam (PAI). Edukasia : Jurnal Penelitian Pendidikan Islam. 9 (2). http://dx.doi.org/10.21043/edukasia.v9i2.773.

Jahroh, N. N. 2018. Pengembangan Tes Tertulis Pendidikan Agama Islam Berbasis Online Mengunakan Google Form pada Materi Kewajiban Menuntut Ilmu dan Haji Kelas X SMA Swadhipa Natar. Skripsi Sarjana, Fakultas Tarbiyah dan Keguruan, Universitas Islam Negeri (UIN) Raden Intan, Lampung. http://repository.radenintan.ac.id/4459/

Kunandar. 2014. Penilaian Autentik (Penilaian Hasil Belajar Peserta Didik Berdasarkan Kurikulum 2013) Suatu Pendekatan Praktis. Cet. 3. Jakarta: Raja Grafindo Persada.

Kusumawati, T. 2014. Pengembangang Instrumen Penilaian Ranah Afektif Mata Pelajaran Akidah Akhlak. Journal of Research and Educational Research Evaluation, 3 (1). https://journal.unnes.ac.id/sju/index.php/jere/article/view/4393.

Moloeng, L. J. 2005. Metodologi Penelitian Kualitatif. Bandung: PT Remaja Rosdakarya. 6

Muchith, M. S. 2016. Guru PAI yang Profesional. Quality, 4(2). http://dx.doi.org/10.21043/quality.v4i2.2121

Muntaha, A., Anwar, E. S. 2020. Penerapan Model Matematika untuk Mencegah Penyebaran Covid-19 di Sektor Pendidikan Indonesia di Era New Normal, MAJU: Jurnal Ilmiah Pendidikan Matematika, 7(2). https://ejournal.stkipbbm.ac.id/index.php/mtk/article/view/492. 
Mustakim, U. S. 2020. Efektivitas Pembelajaran di Era New Normal Terhadap Hasil Belajar Mahasiswa Pada Mata Kuliah Matematika Diskrit. Uniqbu Journal of Exact Sciences (UJES), 1(1). https://doi.org/10.47323/ujes.v1i1.15

Nurbudiyani, I. 2013. Pelaksanaan Pengukuran Ranah Kognitif, Afektif, dan Psikomotor pada Mata Pelajaran IPS Kelas III SD Muhammadiyah Palangkaraya. Anterior Jurnal, 13 (1). https://doi.org/10.33084/anterior.v13i1.295.

Rahardja, U., Lutfiani, N., dan Alpansuri, M. S. 2018. Pemanfaatan Google Formulir sebagai Sistem Pendaftaran Anggota pada Website Aptisi.or.id. Jurnal Ilmiah Sisfotenika, 8(1). http://dx.doi.org/10.30700/jst.v8i2.401

Rohmad. 2015. Pengembangan Instrumen Evaluasi Domaian Mata Pelajaran Aqidah Akhlak. Purwokerto: STAIN Press

Saftari, M., dan Fajriah, N. 2019. Penilaian Ranah Afeketif dalam Bentuk Penilaian Skala Sikap untuk Menilai Hasil Belajar. Education: Jurnal Ilmu Pendidikan dan Ilmu Kependidikan, 7 (1), https://doi.org/10.35438/e.v7i1.164.

Setiadi, H. 2016. Pelaksanaan Penilaian pada Kurikulum 2013. Jurnal Penelitian dan Evaluasi Pendidikan, 20(2). https://doi.org/10.21831/pep.v20i2.7173.

Sudjiono, A. 1996. Pengantar Evaluasi Pendidikan. Jakarta: Grafindo Persada.

Sukanti. 2011. Penilaian Afektif dalam Pembelajaran Akuntasi. Jurnal Pendidikan Akuntansi Indonesia, 9 (1), https://doi.org/10.21831/jpai.v9i1.960.

Winkel, W.S. 2004. Psikologi Pengajaran Yogykarta: Media Abadi.

Suprabowo, G Y. A. 2020. Memaknai Hospitalitas di Era New Normal. HARVESTER: Jurnal Teologi dan Kepemimpinan Kristen, 5 (1). https://doi.org/10.52104/harvester.v5i1.29. 